\title{
Restoration of the bull kelp Nereocystis luetkeana in nearshore rocky habitats
}

\author{
Laura T. Carney ${ }^{1, *}$, J. Robert Waaland ${ }^{2}$, Terrie Klinger ${ }^{3}$, Kern Ewing ${ }^{4}$ \\ ${ }^{1}$ Department of Biology, San Diego State University, San Diego, California 92182, USA \\ ${ }^{2}$ Department of Biology, University of Washington, Box 355325, Seattle, Washington 98195, USA \\ ${ }^{3}$ School of Marine Affairs, University of Washington, 3707 Brooklyn Avenue NE, Seattle, Washington 98105, USA \\ ${ }^{4}$ Environmental Horticulture, Botanic Gardens, University of Washington, Box 354115, Seattle, Washington 98105, USA
}

\begin{abstract}
Anthropogenic disturbances such as shoreline development and sediment loading can reduce or eliminate Nereocystis luetkeana populations and commercially important species associated with $N$. luetkeana. Hence, kelp restoration will become increasingly important in urbanized nearshore areas. Techniques to establish $N$. luetkeana populations in the northwestern waters of Washington State, USA, were examined and compared: (1) out-planting recently settled zoospores and microscopic sporophytes ( 0.5 to $1.0 \mathrm{~mm}$ blade length) grown in laboratory culture, in the field onto natural substrate, and at elevated positions, and (2) transplanting juvenile sporophytes $(<15 \mathrm{~cm}$ stipe length) from natural populations, bypassing the culturing phase. Juvenile transplants were found to be more successful than cultured out-plants. The restoration cost for juvenile transplants was 12 US dollars (USD) per installed plant with a maximum cost estimate of $200 \mathrm{USD} \mathrm{m}^{-2}$. These had a 10 to $30 \%$ higher survival rate than previously reported kelp transplant efforts using larger individuals. The collection of smaller individuals for transplanting imposes smaller ecological costs to natural populations than does the collection of larger, established plants. Stipe breakage caused by the grazing gastropod Lacuna vincta posed the largest limiting factor on transplant survival. Lack of survival among the out-planted zoospores and microscopic sporophytes indicates that other methods will be more successful. Restoration efforts in the nearshore marine environment will benefit from an adaptive management approach in which techniques can be tailored to the specific physical and biological conditions at the restoration site.
\end{abstract}

KEY WORDS: Kelp restoration - Nereocystis - Adaptive management - Transplanting kelp · Out-planting kelp $\cdot$ Sedimentation $\cdot$ Grazing

\section{INTRODUCTION}

Nereocystis luetkeana (Mertens) Postels et Ruprecht is the structurally dominant, canopy-forming, macroalgal species in the Pacific Northwest of North America. It occurs along rocky shores from below the lowest low tide to $18 \mathrm{~m}$ (Kruckeberg 1991). N. luetkeana populations support herbivores, detritivores, and their associated food webs (Duggins 1988). The forest structure common to $N$. luetkeana provides critical habitat for a number of important commercial and sport species including salmonids Oncorhynchus spp., juvenile surf smelt Hypomesus pretiosus, rockfish Sebastes spp., lingcod Ophiodon elongatus, Dungeness Cancer magister and rock crab Cancer productus (Duggins 1988, Shaffer \& Parks 1994, Shaffer 2004). Detached N. luetkeana also provides habitat as beach wrack (Kozloff 1993) and drift mats (Shaffer et al. 1995). Kelps play an important role in regulating nutrients by assimilating nitrogen and phosphorus directly from the water for thallus growth (Lobban \& Harrison 1994). This process is utilized by operators of fish farming enterprises who have used kelps to ameliorate nutrient loading (Ahn et al. 1998, Lüning \& Pang 2003). By taking up carbon dioxide and releasing oxygen, kelp forests can also offset oxygen depletion from biological and chemical 
oxygen demand (B.O.D. and C.O.D.) processes, and can serve as both a carbon sink (Merrill \& Gillingham 1991a, Delille et al. 2000) and a source of dissolved organic carbon (Eckman \& Duggins 1991).

Like most nearshore marine vegetation, kelp beds are adversely impacted by a wide variety of humancaused disturbances including sedimentation (Merrill \& Gillingham 1991a, Cheney et al. 1994, Shaffer \& Parks 1994), oil spills (Antrim et al. 1995), increased levels of metals, herbicides and detergents in the water column (Hopkins \& Kain 1978, Chung \& Brinkhuis 1986), ultraviolet radiation (UVR) (Swanson \& Druehl 2000, Hoffman et al. 2003), and invasions by nonnative species (Thom \& Hallum 1990, Britton-Simmons 2004). Due to the increasing frequency and severity of these impacts, it is prudent to investigate cost-effective and adaptive methods for restoring kelp beds and the communities they support.

Large-scale kelp restoration projects have been successful but require large budgets or excessive monitoring and maintenance commitments, and therefore are not feasible for smaller-scale projects. The San Onofre Nuclear Generating Station (SONGS) mitigation used a substrate-based technique (Ambrose 1994). SONGS budgeted 4 to 6 million US dollars (USD) to establish 61 ha of kelp forest over a 2 yr period (Southern California Edison (2004) Kelp reef project; www.sce.com/PowerandEnvironment/PowerGeneration/ MarineMitigation/KelpReefProject.htm). Additional reviews of this technique were done by Jara \& Cespedes (1994), Reimers \& Branden (1994), and Terawaki et al. (2001). Long-line cultivation was used for the Elliot Bay Marina (EBM) mitigation in Seattle, WA (Merrill 1991, Merrill \& Gillingham 1991a) and though the results were rapid, the managers reported that a large amount of time was spent maintaining the long-line structure and repairing damages caused by pelagic debris (D. Cheney pers. comm.).

As the need for restoration increases, smaller-scale projects will become more common and will benefit from methods (1) that are less costly, (2) logistically easy to implement, and (3) do not require constant monitoring and maintenance. Simpler and less costly restoration methods are described by Devinny \& Leventhal (1979) who cultured Macrocystis pyrifera (Linnaeus) C. Agardh sporophytes on $5000 \mathrm{~m}$ of twine that were then tied directly to rocks in a breakwater in Los Angeles Harbor, CA. This method was adapted from North's technique $(1971,1976)$ of culturing $M$. pyrifera sporophytes on plastic sheets and then scraping them off at the out-plant site. It was estimated that only 1 out of 100000 embryonic sporophytes developed into a mature plant (North 1976). Transplanting larger sporophytes has also been successful. Hernandez-Carmona et al. (2000) reported that by using transplanting alone, 2 divers could establish a $1875 \mathrm{~m}^{2}$ M. pyrifera kelp forest in $2 \mathrm{yr}$.

In the Pacific Northwest, juvenile Nereocystis luetkeana ( $<30 \mathrm{~cm}$ stipe length) and other kelps tend to be most abundant in the early spring months, generally between late February and early March (Maxell \& Miller 1996, L. T. Carney, J. R. Waaland, T. Klinger, pers. obs.). Many of these plants recruit in the mid to low intertidal zone ( 0 to $-3 \mathrm{~m}$ MLLW) but do not survive the low spring tides that occur after the vernal equinox in this region. Because these shallow populations have a very low probability of surviving to maturity, their collection for transplanting is less likely to negatively impact the persistence of natural populations than are collections made from deeper populations. During these months, small juveniles can also be found growing under established N. luetkeana canopies, some of which are unlikely to survive. Although larger, established plants are available over a longer seasonal period, their collection for transplantation purposes is more likely to have a negative effect on natural populations.

For purposes of studying brown macroalgae in the field, other methods including out-planting and transplanting have been employed and are reviewed by Carney (2003). We adapted several of these techniques for restoration purposes, specifically to establish an initial generation of Nereocystis luetkeana, the propagules of which could sustain the population in the next generation. Because culturing the microscopic sporophyte stage from spores can require up to $4 \mathrm{wk}$ in the laboratory, eliminating this culture requirement by out-planting recently settled zoospores would be advantageous in large-scale restoration efforts. Accordingly, we tested the hypothesis $\left(\mathrm{H}_{1}\right)$ that, when out-planted, recently settled zoospores and microscopic sporophytes of $N$. luetkeana will develop into macroscopic sporophytes with equal success. Because benthic microscopic stages are at risk of being consumed by herbivores and buried by sediments, we also tested the hypothesis $\left(\mathrm{H}_{2}\right)$ that $N$. luetkeana out-plants (zoospores and microscopic sporophytes) will have greater survival when elevated above the substratum, where they have a spatial refuge from herbivory and are less vulnerable to sediment deposition. To address the potential use of smaller juveniles in restoration, we hypothesized $\left(\mathrm{H}_{3}\right)$ that small juvenile $N$. luetkeana transplants $(<15 \mathrm{~cm}$ stipe length) will re-establish and persist to reproductive maturity.

\section{MATERIALS AND METHODS}

Study sites. Two study sites in northwestern Washington, USA (Fig. 1) were chosen to represent areas 


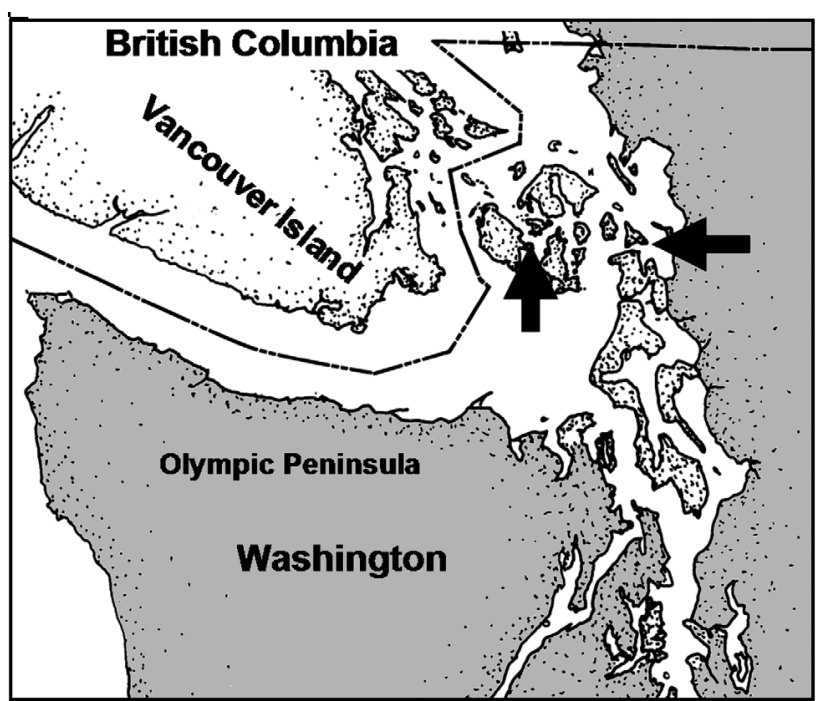

Fig. 1. Map of Washington State, USA, showing Cantilever Point (left arrow) and Saddlebag Island (right arrow)

where Nereocystis luetkeana might establish and survive to maturity. N. luetkeana forms a natural persistent bed in the north cove of Saddlebag Island $\left(48^{\circ} 32.93^{\prime} \mathrm{N}, 122^{\circ} 33.41^{\prime} \mathrm{W}\right)$ in Padilla Bay. At a second site, N. luetkeana previously was established experimentally (Duggins et al. 2001) at Cantilever Point on San Juan Island $\left(48^{\circ} 32.84^{\prime} \mathrm{N}, 123^{\circ} 0.23^{\prime} \mathrm{W}\right)$ in the San Juan Archipelago. Both sites are characterized by serpentine bedrock that is covered in places by shale and silt. Saddlebag Island is dominated by an assemblage of large brown algae, including Laminaria bongardiana Postels et Ruprecht, L. saccharina (Linnaeus) Lamouroux, Costaria costata (C. Agardh) Saunders, Sargassum muticum (Yendo) Fensholt, various species of filamentous algae (mostly Ceramiales, phylum Rhodophyta), and Ulva spp. (phylum Chlorophyta). The assemblage at Cantilever Point has been characterized by Neushul (1967) and by Duggins \& Eckman $(1994,1997)$ for rocky substrate in the shallow subtidal zone of the San Juan Archipelago.

Site characterizations. A $15 \mathrm{~m}$ transect was established along the north-facing bank of Saddlebag Island and the southwest-facing bank of Cantilever Point, between -3.5 to $-5.0 \mathrm{~m}$ MLLW (U.S. tidal datum). The most conspicuous grazer species observed along each transect throughout the study were identified to species.

Light and temperature were recorded along each transect every $2 \mathrm{~h}$ for June and July 2003. Light readings were recorded in lumens $\mathrm{ft}^{-2}$ (reported here in lumens $\mathrm{m}^{-2}$ ) by 3 synchronized $\mathrm{HOBO}^{\circledR}$ LI data loggers (Onset Computer) deployed at the mid- and endpoints of each transect. These light measurements were aver- aged and used to characterize and then compare the study sites, and were not used to quantify light availability for photosynthesis. Although it is most informative to report light measurements as irradiance $\left(\mu \mathrm{E} \mathrm{m} \mathrm{m}^{-2}\right.$ $\mathrm{s}^{-1}$ ), we were limited by the instrumentation available to us. To avoid reporting irradiances based on rough and possibly inaccurate conversions, we have reported only the maximum irradiance for each site using an approximate conversion from Lüning (1980) for which data (lumens $\mathrm{m}^{-2}$ ) are divided by 49.5 . Temperature was recorded by 2 synchronized $\mathrm{HOBO}^{\circledR} \mathrm{H} 8$ data loggers (Onset Computer) deployed along each transect.

Turbidity was measured every 2 wk from September 2002 to August 2003 with a $30 \mathrm{~cm}$ marine Secchi disk (Secchi depth).

Seawater salinity was measured in the laboratory on an automatic temperature-compensated hand refractometer (American Optical, Scientific Instrument Division) from seawater samples $(120 \mathrm{ml})$ that were collected every 2 wk by a diver during the spring and summer of 2003.

Sediment accumulation was measured from December 2002 to July 2003 using 3 sediment traps installed at the endpoints and midpoints of each transect. These were constructed by wedging a $14 \mathrm{ml}(17 \times 100 \mathrm{~mm})$ polypropylene centrifuge tube into a leveled upright section of PVC pipe (5 $\mathrm{cm}$ in length) attached to the substrate with epoxy. The centrifuge tubes used for the traps had a height to width (H/W) ratio of 5.6. A H/W ratio between 4.4 and 6.4 is ideal for sites with moderate current velocity (Gardner 1980). Although not measured in this study, Duggins et al. (2001) found average current speed at Cantilever Point (-8 m MLLW) to be less than $10 \mathrm{~cm} \mathrm{~s}^{-1}$ and velocities at Saddlebag Island were suspected to be similar (authors' pers. obs.). Sediment height in the tubes was measured in the field every 2 wk with a ruler by a diver. After measurement, the tubes were cleared of all sediment and repositioned in the PVC pipe base. Data were standardized by dividing the total sediment height for each measurement by the number of full days it was deployed, not counting day of deployment or measurement. Comparisons were made between sites by averaging height-per-day measurements to get a monthly average for each site.

Out-plant experiments. To test $\mathrm{H}_{1}$, we out-planted experimental substrates seeded either with recently settled zoospores ( $Z$ treatment), or with microscopic sporophytes (MS treatment: 0.5 to $1.0 \mathrm{~mm}$ blade length). Control treatments consisted of identical experimental substrates to which no seed material was added (control treatment, C). In order to test $\mathrm{H}_{2}$, we compared survival success between out-plants attached at substrate level versus at elevated positions ( $7 \mathrm{~cm}$ above substrate). 
Twenty $30 \mathrm{~cm}^{2}$ plots were marked along transects at both sites with numbered stainless-steel washers. All plots had slopes less than $45^{\circ}$, similar aspects and surfaces which were smooth enough for an epoxy attachment. Prior to all epoxy applications, the rock surface was cleared by hand of macroalgae and diatom/silt cover then brushed with a stainless-steel wire brush to remove barnacles Balanus sp. and any fleshy algae remaining on the substrate. At Cantilever Point, which was generally covered with encrusting coralline algae, a chisel and hammer were used to remove the top layer of rock. Three $7 \mathrm{~cm}$ sections of $1.3 \mathrm{~cm}$ thick wall PVC pipe were installed in each plot at both sites. Plots were kept clear of macroalgae throughout the study.

In May of 2003, we initiated MS treatment cultures from fragments from a unialgal vegetative seed stock of Nereocystis luetkeana gametophytes collected in 1996 at Minnesota Reef $\left(48^{\circ} 32.14^{\prime} \mathrm{N}, 122^{\circ} 59.16^{\prime} \mathrm{W}\right)$, near Friday Harbor. These had been previously separated into male and female gametophyte stocks and maintained vegetatively under low-light conditions at $10^{\circ} \mathrm{C}$ as part of the University of Washington culture collection (E. C. S. Duffield pers. comm.). Equal amounts of seed stock from separate batches of male and female gametophytes were pipetted into a chilled Waring ${ }^{\circledR}$ blender whose cutting blade had been replaced with a double-edged razor blade. Sterilized seawater (125 ml) was added and the suspension was blended for $45 \mathrm{~s}$ in 5 to $10 \mathrm{~s}$ pulses. This method is commonly used to induce fertility in kelp gametophytes (Vadas 1972, Bolton \& Lüning 1982, Tom Dieck 1992, Duggins et al. 2001). Sample drops of the blended seed stock were examined microscopically to confirm densities of at least two 3 to 5 cell fragments per $0.15 \mathrm{~mm}^{2}$. The suspension was used to inoculate 86 polystyrene sterile/gamma irradiated Petri dishes $(35 \times 10 \mathrm{~mm}$ style), each containing $4 \mathrm{ml}$ of enriched seawater, with an inoculum volume of $0.25 \mathrm{ml}$ seed stock per dish. This amount yielded an approximate settlement density of 5 reproductive gametophytes per $1 \mathrm{~mm}^{2}$ in each dish. Full-strength (3.5 ml enrichment $\mathrm{l}^{-1}$ of seawater) Guillard's f/2 algal original recipe culture medium (McLachlan 1973) was used for the first $2 \mathrm{wk}$ of the culture phase to increase nutrient availability to developing gametophytes. This had been observed to increase gamete production in earlier trial dishes (L. T. Carney pers. obs.). Medium was changed weekly and reduced to half strength enrichment $\left(1.75 \mathrm{ml}\right.$ enrichment $\mathrm{l}^{-1}$ of seawater) for the third week in culture. Cultures were grown at $10^{\circ} \mathrm{C}$ under long day conditions (16L:8D), with a light level of approximately $70 \mu \mathrm{E} \mathrm{m} \mathrm{m}^{-2} \mathrm{~s}^{-1}$. Microscopic sporophytes developed within 2 wk of inoculation. These were out-planted 21 to $23 \mathrm{~d}$ after inoculation, when at least 3 microscopic sporophytes (blade less than $1 \mathrm{~mm}$ in length) were observed in each dish.
In early June 2003, Z treatment cultures were started from sori collected from 5 individuals of Nereocystis luetkeana from Turn Rock $\left(48.536^{\circ} \mathrm{N}, 122.963^{\circ} \mathrm{W}\right)$ near Friday Harbor, San Juan Island, WA. Only ripe, healthylooking sori were taken. Sori were wrapped in moist paper towels and desiccated at $4^{\circ} \mathrm{C}$ for $24 \mathrm{~h}$. Zoospore release was induced by soaking the desiccated sori in 11 of sterilized $10^{\circ} \mathrm{C}$ seawater for $30 \mathrm{~min}$. Sori were then removed and discarded. This seed stock was left to settle at $10^{\circ} \mathrm{C}$ for 30 to $40 \mathrm{~min}$ and then decanted through a sieve into a sterilized beaker. The spore concentration of the seed stock was measured using a Spotlite ${ }^{\mathrm{TM}}$ hemacytometer (1/400 $\mathrm{mm}^{2}, 1 / 10 \mathrm{~mm}$ deep) under a microscope (10× objective). An additional 86 Petri dishes were inoculated at a concentration of $1 \times 10^{4}$ spores $\mathrm{ml}^{-1}$ as suggested by Reed (1990) for Macrocystis pyrifera. The dishes were grown as described above, except that halfstrength seawater medium was used from the time of inoculation. These were out-planted 3 to $5 \mathrm{~d}$ after inoculation. Zoospore treatments had a zoospore settlement density of 100 spores $\mathrm{mm}^{-2}$.

In mid-June 2003, Petri dishes for both Z and MS treatments were installed along the transect at each site. Transportation to the field and installation methods are described by Carney (2003). Some Petri dishes were brought to the field but not out-planted. These served as a control for the effect of transportation to the field site and were monitored in the laboratory through the end of July in order to observe the effect of transport to the field, as well as culture viability. Blades developed on all monitoring dishes.

After out-planting, each plot contained 2 sets of the C, Z, and MS treatments, 1 set at substrate level and 1 elevated. Presence or absence of blades was noted for each out-planted Petri dish during 2 censuses separated by 2 wk in July 2003. Presence and absence was measured instead of total blade number because each dish would be pruned down to 1 blade in order to reduce mortality by competition if this method was used for restoration purposes. On the final census in July 2003, all remaining dishes were collected from the field and transported on ice to the laboratory where presence of $N$. luetkeana was determined using a dissecting microscope.

Out-planting experiments followed a $2 \times 2 \times 3$ randomized block design and the levels were site, elevation and life stage.

Juvenile transplant experiment. To test $\mathrm{H}_{3}$, juvenile Nereocystis luetkeana plants were transplanted from a natural kelp bed along the shoreline of Shaw Island in the San Juan Archipelago to the experimental transect at Cantilever Point. In March 2003, a diver collected 46 juvenile plants ( 6 to $12 \mathrm{~cm}$ stipe length, Fig. 2a) from the shallow edge ( $-3 \mathrm{~m}$ MLLW) of a kelp bed just south of Point George $\left(48^{\circ} 33.66^{\prime} \mathrm{N}, 122^{\circ} 59.22^{\prime} \mathrm{W}\right)$ on the 

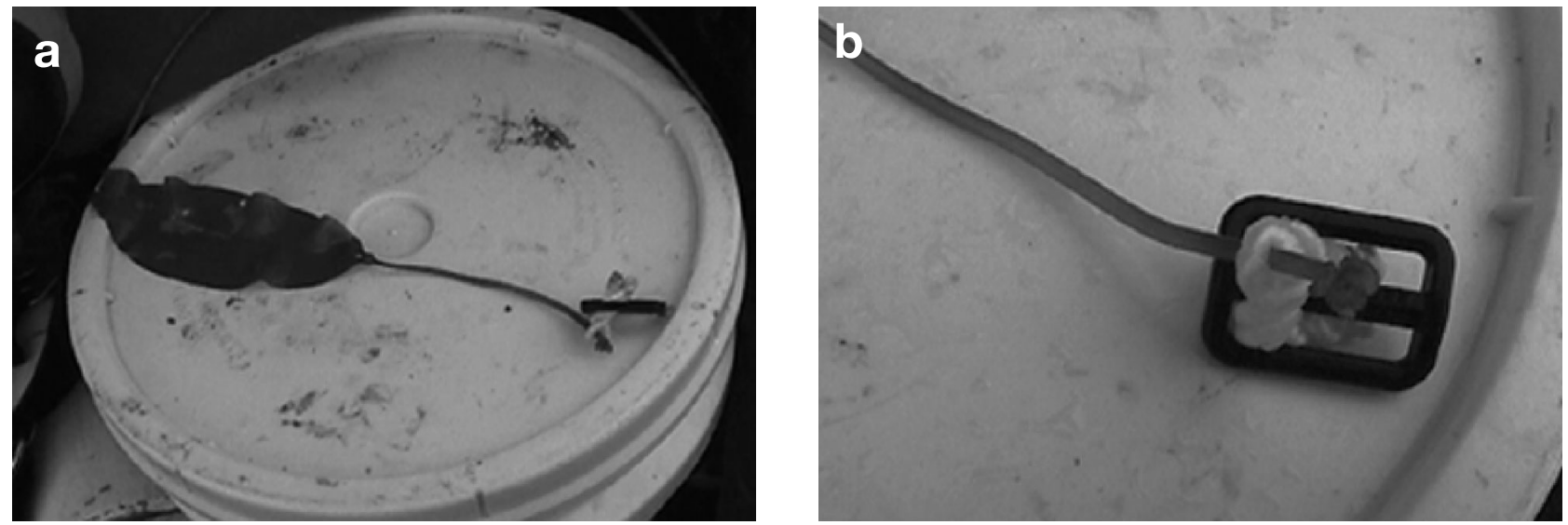

Fig. 2. Nereocystis luetkeana. (a) Juvenile transplant with $10 \mathrm{~cm}$ stipe length. (b) Close-up of a holdfast prepared for attachment and inserted into rope section and clip

southwestern shore of Shaw Island (across the San Juan Channel from Cantilever Point). At the surface, each juvenile holdfast was inserted through the middle of a $7 \mathrm{~cm}$ nylon rope section $(0.6 \mathrm{~cm}$ diameter $)$. The nylon rope previously had been soaked for several hours in distilled water, then overnight in a sodium carbonate (Washing Soda) solution $\left(20 \mathrm{~g} \mathrm{l}^{-1}\right)$ and then rinsed several times in distilled water in order to remove any dyes and other toxic compounds that may have been added by the manufacturer. Holdfasts were inserted into the rope in such a way that part of the holdfast was touching the rope (Fig. 2b).

Extra care was taken to avoid any damage to the stipe or holdfast, as even a small nick could cause future stipe or holdfast failure (Duggins et al. 2001). The rope sections were each threaded through a hard plastic clip and transplants were placed into a seawater-soaked pillowcase and transported to Cantilever Point, across the San Juan Channel. Within $1.5 \mathrm{~h}$ of collection, a diver transported the juveniles to Cantilever Point and out-planted 32 individuls along the transect. Each clip, with juvenile, was attached with marine epoxy directly to the cleared substrate, taking special care to avoid getting fresh epoxy on any part of the juvenile thallus. Once attached, the juvenile holdfast was within a few centimeters of the substrate.

Percent survival was calculated on each subsequent visit through July 2003. Reason for failure, when it occurred, was recorded for each transplant loss. A method failure was recorded if the clip, rope, or epoxy failed. Holdfast, stipe, or bulb failure was determined based on remnant tissue (Duggins et al. 2001). Stipe length was recorded for each surviving transplant 24 and 119 d after transplanting. Grazers (gastropods only) were counted and identified on each remaining transplanted stipe at Cantilever Point during a dive
119 d after transplanting. Echinoderms were never observed in the plots at either site.

Cost benefit analysis. The time requirement and monetary costs for each restoration method were determined and weighed against establishment success. The cost per plant was estimated by dividing the total cost of each method by the number of plants installed for each technique rather than the number that actually established. This was done because there is a cost involved with installing plants regardless of survival. The establishment success was then compared in light of the implementation costs.

\section{RESULTS}

\section{Biological and environmental site conditions}

At Cantilever Point, we continually observed grazers in the plots. The most conspicuous of these were identified as Lacuna vincta, Margarites pupillus, Calliostoma ligatum, Bittium eschrichtii and Tonicella lineata. Two weeks after the June 2003 out-planting, we observed these species in the majority of the Petri dishes.

Average daylight irradiances are shown in Fig. 3. For both sites, maximum irradiances (1370 lumens $\mathrm{m}^{-2}$ or approximately $27.6 \mu \mathrm{E} \mathrm{m}^{-2} \mathrm{~s}^{-1}$ for Saddlebag Island and 4500 lumens $\mathrm{m}^{-2}$ or approximately $90 \mu \mathrm{E} \mathrm{m} \mathrm{m}^{-2} \mathrm{~s}^{-1}$ for Cantilever Point) reached saturating levels (1000 to 2000 lumens $\mathrm{m}^{-2}$ or approximately 20 to $40 \mu \mathrm{E} \mathrm{m}^{-2} \mathrm{~s}^{-1}$ ) reported for Nereocystis luetkeana growth by Vadas (1972). It should be noted that irradiances were lower at Saddlebag Island than at Cantilever Point on average; however, light was not limiting at either site.

Average temperatures are shown in Fig. 4. Temperature ranged from 10 to $16^{\circ} \mathrm{C}$ for Saddlebag Island and 

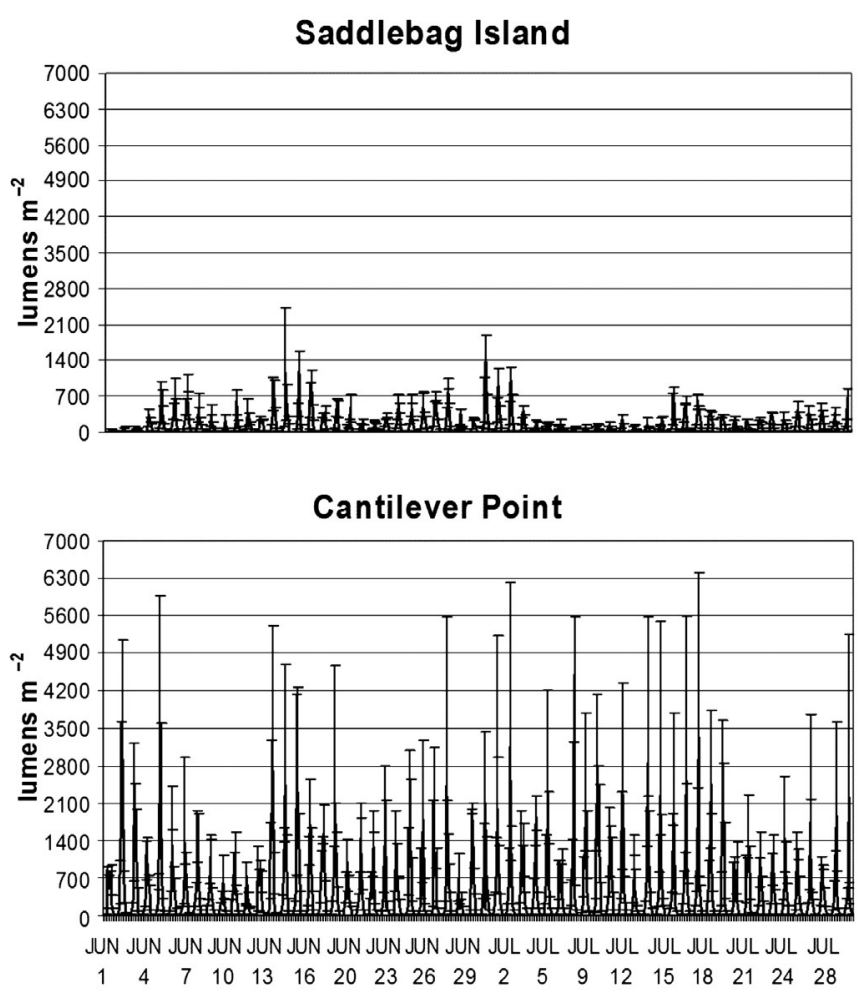

Fig. 3. Light quantity. Average light quantities recorded along the transect at each study site between June and July 2003. These data were recorded in lumens $\mathrm{ft}^{-2}$ and reported in lumens $\mathrm{m}^{-2}$ by multiplying original data by 10.76 . Error bars indicate the standard deviation (SD)

from 9 to $14^{\circ} \mathrm{C}$ for Cantilever Point. These temperatures are within the range in which Nereocystis luetkeana is known to develop and recruit (Vadas 1972, Maxell \& Miller 1996). Slightly higher temperatures were recorded at Saddlebag Island than at Cantilever Point. This is likely due to the fact that Saddlebag Island is located in Padilla Bay, an expansive area of shallow mudflats, while Cantilever Point is influenced by deeper, well-mixed water.

Seawater sample salinity showed continuous readings of $29 \%$ for Saddlebag Island and 30\% for Cantilever Point. These values are conducive to Nereocystis luetkeana development and within the range reported for populations in the Puget Sound region (Maxell \& Miller 1996).

Average monthly Secchi depth and sediment accumulation are shown in Fig. 5. Secchi depth averaged $4.2 \mathrm{~m}$ for Saddlebag Island (mean $\pm 1.3 \mathrm{SD}$ ) and $7.7 \mathrm{~m}$ for Cantilever Point (mean $\pm 1.6 \mathrm{SD}$ ). The sites were significantly different in terms of Secchi depth (pairedsamples $t$-test, $\mathrm{p}=0.000$ ) and sedimentation (pairedsamples $t$-test, $\mathrm{p}=0.003)$. Secchi depth was consistently more shallow, i.e. turbidity was higher, at

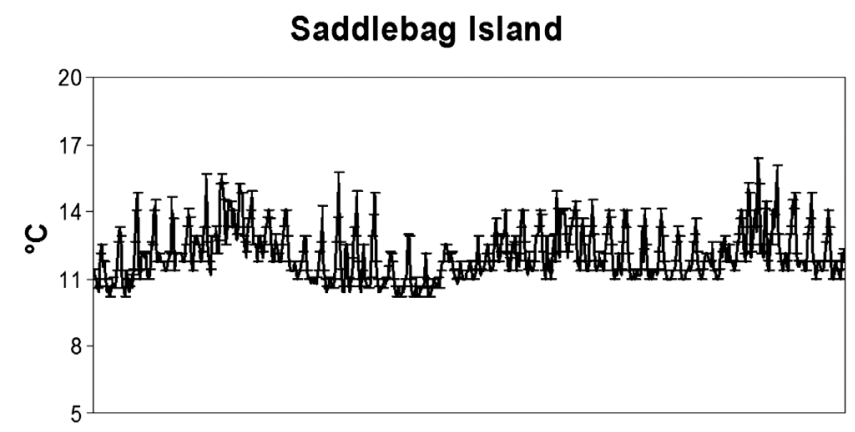

Cantilever Point

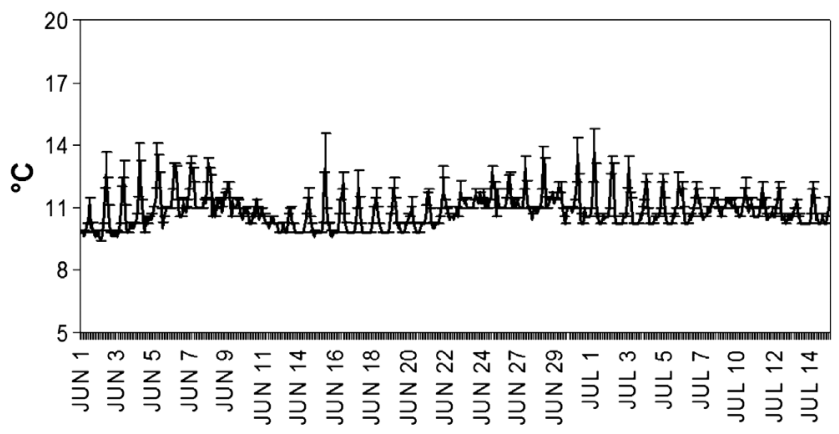

Fig. 4. Temperature. Average temperatures recorded along the transect at each study site between June and mid-July 2003. Error bars indicate the standard deviation (SD)

Saddlebag Island than at Cantilever Point. Average sediment accumulation per day was $0.097 \mathrm{~cm}$ (mean \pm $0.016 \mathrm{SE}$ ) at Saddlebag Island and $0.051 \mathrm{~cm}$ (mean \pm 0.011 SE) at Cantilever Point. Accumulation at Saddlebag Island was approximately twice that for Cantilever Point.

\section{Cultured out-plant survival}

No recruitment was observed at either site on the dishes out-planted in June 2003 during the first and second July 2003 censuses. Over the experimental period, $52.5 \%$ (42 out of 80 ) of all out-planted cultured dishes were lost at Saddlebag Island. Sparse fouling macroalgae, chain-forming diatoms and juvenile barnacles were observed on most of the out-planted dishes. A layer of sediment $(\sim 1 \mathrm{~cm})$ was present in all dishes. In contrast, only $11 \%$ (9 out of 80 ) of all outplanted Petri dishes were lost at Cantilever Point. Half of the remaining dishes were clean of all algal growth except for chain-forming diatoms and gastropod grazers which were observed on a third of the dishes. Because Nereocystis luetkeana was not observed on any of the substrates out-planted with cultured kelp in this study, $\mathrm{H}_{1}$ and $\mathrm{H}_{2}$ could not be tested. 

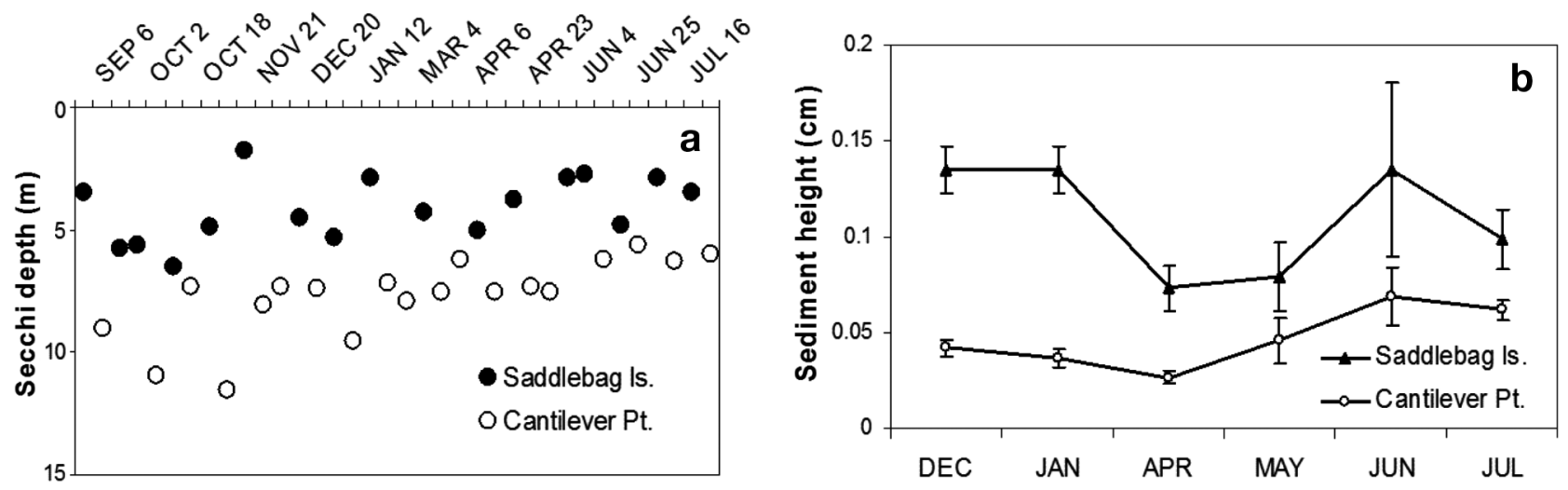

Fig. 5. (a) Secchi depth and (b) sediment height measured at both study sites from 2002 to 2003. Note the different start dates. Error bars indicate the standard error (SE) for monthly data (monthly values are based on the average of all sampling dates during the month, calculated as the average of the 3 sediment traps along the transect)

\section{Juvenile transplant establishment}

The number of transplants that survived through the study and the reasons for failure among those that did not survive are shown in Table 1. Average stipe length is reported when available. Nine of the original 32 transplants $(28 \%)$ survived throughout the study period. These individuals produced and shed sori for at least $80 \mathrm{~d}$, a conservative estimate considering sori were first observed on the blades $56 \mathrm{~d}$ after transplanting and their production could have been initiated anytime between then and the time of the previous site visit, $37 \mathrm{~d}$ after transplanting. The mean number of days the transplants survived was 56 d, although the 9 surviving at the end of the study persisted longer than others.

A mortality rate of $56 \%$ occurred for the first $24 \mathrm{~d}$ and was primarily due to method failure. The majority of the method failures $(97 \%)$ were due to a break in the epoxy bond between the clip and substrate. The holdfasts of all remaining transplants were observed to have established within $56 \mathrm{~d}$ after transplanting.

Aside from the period between 10 and $24 \mathrm{~d}$ after transplanting, stipe failure remained constant at $3 \%$ throughout the study. Holdfast failure was never observed during the experiment.

During the grazer survey at the end of the study, an average of 14 grazers was counted per transplanted stipe. Of 140 gastropod grazers observed on the stipes of the 10 individuals remaining at the time of the survey, 128 (91\%) were Lacuna vincta and 12 (9\%) were Margarites pupillus and Calliostoma ligatum. L. vincta were also observed (but not quantified) on the pneumatocysts and blades of the transplants and $M$. pupillus and $C$. ligatum were only observed on the lower portions of the stipes ( $<1 \mathrm{~m}$ from holdfast) and on the holdfasts of the transplants.

\section{Cost benefit analysis \\ Cultured out-plants}

To out-plant 80 seeded Petri dishes (potentially yielding 1 plant each after pruning) a total of 50 person hours were required for collecting sori, culturing, site preparation, out-planting the seeded substrate and monitoring and maintaining the out-plants (Table 2).

Table 1. Nereocystis luetkeana. Transplant survival and reason for failure surveyed every 2 wk during the $135 \mathrm{~d}$ of the study. Data are shown as a percentage of the 32 original transplants, for each survival count. The number of individuals that each percentage represents is shown in parentheses. Stipe length range is included when available

\begin{tabular}{|cccccc|}
\hline \multirow{2}{*}{$\begin{array}{c}\text { Days after } \\
\text { transplanting }\end{array}$} & $\begin{array}{c}\text { Stipe length } \\
(\mathrm{m})\end{array}$ & $\begin{array}{c}\text { Survivors } \\
(\%)\end{array}$ & \multicolumn{4}{c|}{ Method } & Sailure type (\%) \\
\hline 0 & $0.06-0.12$ & $100(32)$ & - & - & - \\
10 & & $84.4(27)$ & $12.5(4)$ & $3.1(1)$ & \\
24 & $0.5-1$ & $43.8(14)$ & $18.8(6)$ & $18.8(6)$ & $3.1(1)$ \\
37 & & $40.6(13)$ & - & $3.1(1)$ & - \\
56 & $2-3$ & $37.5(12)$ & - & $3.1(1)$ & - \\
70 & & $37.5(12)$ & - & - & - \\
80 & & $34.4(11)$ & - & $3.1(1)$ & - \\
119 & $2.8-4.4$ & $31.3(10)$ & - & $3.1(1)$ & - \\
135 & & $28.1(9)$ & - & $3.1(1)$ & - \\
Total & & $28.1(9)$ & $31.3(10)$ & $37.5(12)$ & $3.1(1)$ \\
\hline
\end{tabular}


Table 2. Cost breakdown for 2 restoration methods tested. Cost per plant is the total cost for each method at 1 site divided by the best-case potential yield of each method: 80 plants for cultured out-planting and 32 for transplanting method. USD: US dollars

\begin{tabular}{|lccc|}
\hline & Rate & $\begin{array}{c}\text { Cultured } \\
\text { out-plants }\end{array}$ & $\begin{array}{c}\text { Juvenile } \\
\text { transplants }\end{array}$ \\
\hline Lab time & $15 \mathrm{USD} \mathrm{h}^{-1}$ & 210 & - \\
Dive time (2 divers) & $15 \mathrm{USD} \mathrm{h}^{-1}$ & 270 & 75 \\
Boat time (1 driver) & $15 \mathrm{USD} \mathrm{h}^{-1}$ & 270 & 150 \\
Boat fuel & $1.50 \mathrm{USD} \mathrm{gal}^{-1}$ & 100 & 50 \\
Materials & & 180 & 107 \\
Total & & 1030 & 382 \\
Cost per plant & & $12.87 \mathrm{USD}$ & $11.93 \mathrm{USD}$ \\
\hline
\end{tabular}

The cost per installed plant was approximately 13 USD, including materials, fuel and hourly rates for divers, lab techs and boat drivers. Because no recruitment was obtained, it can be concluded that the costs far exceeded the benefits.

Juvenile transplants

To transplant 32 plants, a total of 22 person hours were required for site preparation, juvenile collection, transportation and transplantation (Table 2). The cost per transplanted plant was approximately 12 USD, including materials, fuel, and hourly rates for divers and boat drivers. This method resulted in a $28 \%$ survival rate of sexually mature Nereocystis luetkeana, all of which contributed propagules to the surrounding area for at least $80 \mathrm{~d}$.

\section{DISCUSSION}

Transplanting was found to be the most effective method for establishment of reproductive adults, and had the only positive cost benefit. Although over $70 \%$ of the transplants were lost by the end of the study, the survivors all produced sori, and most likely contributed large numbers of spores to the local area for at least $80 \mathrm{~d}$. For the purposes of restoration, we consider losses of this order to be acceptable if surviving individuals promote natural recruitment and interannual persistence at the restoration site.

\section{Factors contributing to the success and failure of juvenile transplants}

Stipe failure was the leading cause of transplant mortality. We attributed stipe failures to damage by grazers, particularly Lacuna vincta, which were abundant on the thallus tissue (lower stipe and holdfast) remaining after stipe failure. Mortality resulting from damage to stipes by grazing $L$. vincta is consistent with the findings of Duggins et al. (2001), who reported that Nereocystis luetkeana juveniles transplanted to Cantilever Point (Cantilever Point at -8 m, MLLW) in 1996 suffered a high degree of stipe failure due to deep incisions caused by grazing L. vincta. However, in contrast to the findings of Duggins et al. (2001), grazer abundance on the transplanted stipes was $33 \%$ lower in this study and the mean number of days the transplants survived (56 d) was more than twice as long as those transplanted in 1996 as reported by Duggins et al. (2001).

The major differences between the 2 studies were the timing of the transplant (October [Duggins et al.] vs. March [this study]) and the size of transplanted sporophytes (3 to $4 \mathrm{~m}$ [Duggins et al.] vs. 6 to $12 \mathrm{~cm}$ [this study]). Light levels and temperature are reduced and may be suboptimal for growth during the late fall, a time when natural populations of Nereocystis luetkeana begin to senesce (Kozloff 1993, Maxell \& Miller 1996). Additionally, increased storm surge in the fall increases the risk that transplants will be lost before they become naturally established. Optimal light and temperature conditions and lower storm surge occur during the spring, making it the best season for transplanting small sporophytes.

The late fall timing of transplanting and the larger size class used may have interacted to increase grazing pressure among Duggins et al.'s 1996 transplants. Martel \& Chia (1991) found that juvenile Lacuna vincta are most abundant in the canopy layer of kelp beds in April through May and then again in the late summer through fall months after the larvae are released by the adults in the understory. After this period, they move down to the understory zone via the stipes. Because Duggins et al. (2001) transplanted older juveniles in the fall, at a time when canopy kelps support large populations of juvenile L. vincta on their fronds, stipe grazing may have been more intense after transplanting. Fewer larvae would be present on plants collected prior to recruitment in April, leading to small populations among the transplanted stands. Furthermore, slower kelp thallus growth rates in the fall could allow higher numbers of grazers to develop on the blades, compared with faster growing plants collected in the spring. In this study, smaller juveniles were transplanted and were noted to be free of grazers along their thalli. Consequently, the timing of transplanting may be an important factor in the success of transplantation efforts in which L. vincta or another canopy recruiter is the dominant grazer. 
It should be noted that a portion of the reported stipe failures in this study could have been caused by damage incurred during collection and transplantation. Young juveniles are highly susceptible to small injuries (nicks and scratches), which can propagate as the plants grow and can cause breakage. Extreme care was taken not to damage the plants during collection, transport and transplanting, and juveniles that showed any signs of damage at the time of installation were discarded. However, it cannot be ruled out that some individuals were transplanted with undetected damage.

Method failure was the second leading cause of mortality and was due to a break in the epoxy hold on the substrate. Attachment via growth of haptera onto the natural substrate corresponded to an immediate decrease in mortality caused by method failure. Similar findings are reported by Hernandez-Carmona et al. (2000) for juvenile Macrocystis pyrifera transplants attached to cut but intact holdfasts of an understory kelp with rubber bands. Establishment by growth and attachment to natural substrates is the primary goal of transplantation. Survival may have been considerably higher in this study if a method that does not rely on an epoxy bond had been used. Duggins et al. (2001) never observed method failure when Nereocystis luetkeana transplants were secured to the bottom with nylon cable ties. However, abrasion from the cable tie could be problematic for younger transplants and would need to be modified. Other mechanical attachment methods that might be adapted for use in restoration are described by Druehl (1978).

\section{Transplant size}

Other researchers have either used or recommended the use of larger-sized transplants ( $>1 \mathrm{~m}$ stipe length) for increased survival (Druehl 1978, Hernandez-Carmona et al. 2000, Duggins et al. 2001, Kawamata 2001, G. Hernandez-Carmona pers. comm.). In this study, transplanting smaller plants was just as effective as larger-sized plants, if not more so, with approximately $20 \%$ more surviving after $45 \mathrm{~d}$ than in previous efforts using larger plants (Duggins et al. 2001).

Individuals collected from areas where they are unlikely to survive to maturity might reasonably be used for these purposes. However, we offer this suggestion with caution, and emphasize that we do not advocate decimation of healthy, established beds for purposes of transplantation. Such action would be inconsistent with the intended purposes and long-term benefits of transplantation for restoration.

Smaller plants are easier to work with due to their size; consequently, a larger number of individuals can be transplanted given a fixed amount of economic re- sources. Higher drag forces are exerted on larger plants (Denny \& Gaylord 2002) and therefore, mortality rates could be increased for larger transplants prior to natural establishment and depending on the attachment method used. Further, due to morphological differences between blades from high and low current areas (Koehl \& Alberte 1988) adult transplants cannot withstand being moved from low to high current sites (Druehl 1978, Kawamata 2001). It may be best to transplant only small $(<30 \mathrm{~cm}$ stipe length) plants that do not have mature blades of a certain morphology and are not already colonized by grazer larvae. Although the availability of younger juveniles limits transplanting to the spring, the present study shows that transplant survival at this time is higher than during other seasons.

\section{Factors contributing to the success and failure of cultured out-plants}

In Washington State, sporophtyes of Nereocystis luetkeana are first visible in late winter and early spring and shed sori throughout the late spring, summer and fall (Maxell \& Miller 1996). In previous trials not reported here, out-planting was performed during the spring, summer and fall months to account for seasonal variation in the success of this technique. No establishment was observed for out-plants regardless of season (Carney 2003). Although the details of the seasonal trials are not reported here, we cannot recommend the use of cultured out-plants for restoration, regardless of season.

Sedimentation was the major limiting factor at Saddlebag Island. Devinny \& Volse (1978) reported a $90 \%$ mortality rate for Macrocystis pyrifera spores covered by a $0.045 \mathrm{~cm}$ thick layer of sediment and showed that sediment can also smother an already attached gametophyte. By these estimates, the sediment observed in the Petri dishes after out-planting $(\sim 1 \mathrm{~cm})$ and the $0.1 \mathrm{~cm} \mathrm{~d}^{-1}$ accumulation rate at Saddlebag Island was sufficient to prevent recruitment, regardless of elevation above the substratum. It is likely that the Petri dishes amplified the negative effects of sedimentation by collecting and holding sediment and are certainly not ideal under these conditions. However, previous trials performed in this study (Carney 2003) but not reported here used a wall-less plastic substrate with the same result. According to the recommendations of Devinny \& Volse (1978), locations such as Saddlebag Island, where rocky substrate is routinely covered with sediment, should be avoided as restoration sites.

Interestingly, natural recruitment is not prevented by sedimentation at Saddlebag Island, and a natural Nereocystis luetkeana population persists there. Garbary et al. (1999) hypothesized that in areas where 
sediment accumulation is high, microscopic $N$. luetkeana germlings growing endophytically in filamentous red algae may experience higher survival. Such a strategy could reduce the negative impacts of high sediment loads. It is possible that the natural population at Saddlebag Island depends on an endophytic relationship between its microscopic stages and red algae for initial survival. Alternatively, natural recruitment at Saddlebag Island may occur during infrequent windows of low or no sedimentation.

Whereas sedimentation was minimal at Cantilever Point, grazers were noted during every dive in and around the installed features. As described in the literature (Robles \& Cubit 1981, Robles 1982, reviewed by Foster \& Sousa 1985), elevating out-plants can be effective in deterring less maneuverable grazers but complex elevation structures can provide refuge to other grazers, particularly coiled snails, fish and amphipods, exaggerating their effects. Coiled snails were continuously observed in the elevated Petri dishes, although they may have served as protection from less maneuverable grazers such as chitons, limpets and echinoids, which were never observed in the dishes. The fact that the Petri dishes collected sediment and seemed to capture or retain gastropod grazers did not allow the effect of elevation to be tested properly at either site. However, elevating or suspending out-plants has been found by other researchers to be advantageous (Devinny \& Leventhal 1979, reviewed by Foster \& Sousa 1985).

The purpose of testing the use of small styrene substrates for restoration was to find inexpensive materials that could be easily installed. Small substrates attached on the bottom to natural rock are less vulnerable to damage caused by pelagic debris than a suspended rope structure but are more vulnerable to sedimentation and grazing. The effects of grazing and silt are largely avoided when out-planting seeded twine (Devinny \& Leventhal 1979, Merrill \& Gillingham 1991a) because the out-plants are raised above the benthic layer and can later be lowered when the plants are larger and less affected by benthic processes. Biodegradable string or twine has been suggested as the ideal substrate for out-planting kelps (L. D. Druehl pers. comm.) due to its hydrophilic quality and maneuverability during installation.

Although out-planting cultured kelp did not result in recruitment in this study, the method has been used successfully in other studies (Hsiao \& Druehl 1973, Devinny \& Leventhal 1979, Deysher \& Dean 1986, Lee \& Brinkhuis 1988, Reed 1990, Merrill \& Gillingham 1991b, Duggins et al. 2001) and it may be advantageous to investigate further for kelp restoration purposes. It would be more cost effective to out-plant an earlier stage (e.g. recently settled zoospores) and reduce time spent in the culture phase. Further work could be done to determine the requirements for success of such a method.

\section{Recommendations for kelp restoration}

The subtidal rocky nearshore is an unpredictable environment; light, temperature, nutrient availability, turbidity, water motion, salinity and grazing pressure all vary with season, depth, and location. Restoration in this environment will benefit from an adaptive management approach, since variation between and within sites is potentially large and is due to factors that remain largely uncontrollable. The concept of adaptive management is outlined in the literature (Lee 1993, Murray et al. 2000, Marmorek 2003). As uncertainties regarding the outcomes of a restoration method increases, this approach becomes more useful because it is aimed at using experimentation to ameliorate them. To augment this approach, it is desirable to test multiple planting techniques at a restoration site prior to a large-scale planting. Combining multiple restoration techniques, such as transplanting and sorus seeding, is recommended in the literature (North 1976, Hernandez-Carmona et al. 2000) and increases the likelihood of success given a high degree of environmental variability. The experience gained from using multiple adaptive techniques allows managers to design a more effective approach for future efforts.

The results of this study reveal some of the uncertainties associated with marine restoration and demonstrate that using planting techniques can be difficult and some degree of failure should be expected. Considering this difficulty, restoration budgets need to be flexible, leaving room for improvement, and in some cases, replacement of a method. With this in mind, important recommendations can be made from the present study and are highlighted below. These and others are described in more detail by Carney (2003).

A restoration site must be chosen carefully in order to avoid unnecessary mortality. When out-planting the microscopic stages, restoration sites where sedimentation rates are high should be avoided. If these sites cannot be avoided, transplanting young juveniles $(<15 \mathrm{~cm}$ stipe length) is recommended because these have developed past the size class most impacted by sedimentation. Although it might be anticipated that a high siltation rate would prevent survival of a second generation at the site, a natural population does persist at the Saddlebag Island site, indicating that natural recruitment occurs even in the presence of sedimentation, perhaps via initial endophytism in understory algae. 
If cultured microscopic stages must be used because juveniles are not available, the out-plantings should be elevated on a device that excludes sediment and grazers. Suspending seeded twine above the bottom may be the best option; however, this should be firmly secured to avoid abrading the plants during periods of current when twine could be dragged across nearby rocks. Dominant grazers should be identified before planting and modifications made accordingly. Elevated treatments may exclude less maneuverable grazers but are useless against herbivorous fish and some gastropods. Grazer exclusion devices, such as cages or nets, should be weighed for cost benefit if these types of grazers are abundant. If increased loss due to grazer inflicted damage is expected, it may be advantageous to clear both the substrate and transplants of grazers on a weekly basis. Planting may also be timed to avoid periods when the dominant grazers are at their highest densities.

Approximately $60 \%$ of all out-planted substrates and $30 \%$ of all transplants were lost in this study due to epoxy failure. Failure could have been caused by residual natural material missed during the substrate cleaning before the epoxy was applied; local faunal activity of river otters Lutra canadensis, sea stars Pisaster ochraceous, Dungeness and red rock crab (Cancer spp.) observed on or around the plots; or, increased water motion. We cannot recommend the use of epoxy for restoration purposes without caveats; however, if an epoxy-based method is used it should be tested at a restoration site prior to any large-scale installations. Using seeded twine for cultured out-plants avoids epoxy use entirely. Methods that tie transplants directly to the substrate seem the most effective in promoting fast establishment and eliminating method based failure (see Druehl 1978, Hernandez-Carmona et al. 2000, Duggins et al. 2001, Kawamata 2001).

Given a $30 \%$ transplant survival rate and a reported natural maximum density of 3 to 6 ind. $\mathrm{m}^{-2}$ (Shaffer 1998), we estimate that Nereocystis luetkeana restoration using transplanting will cost approximately 120 to $200 \mathrm{USD} \mathrm{m}^{-2}$. This calculation is based on the cost per plant reported in Table 2 and is likely an overestimate since it is quite easy to both collect and install a larger number of individuals given the same amount of resources because juveniles are found at high densities in the field. The cost per plant could be markedly reduced by both transplanting more juveniles per unit area and by using a non-epoxy based attachment method as described above. We suggest this due to both the high rate of epoxy failure observed in this study and the high market cost of marine epoxy (approximately 40 USD $\mathrm{l}^{-1}$ for Woolsey ${ }^{\circledR} / \mathrm{Z}^{*} \mathrm{SPAR}^{\circledR}$ epoxy). When transplanting is called for, pilot studies should be performed to identify areas and planting densities that have the appropriate cost-benefit ratios. With practice, greater efficiencies and economies of scale are likely to reduce the cost per plant.

Although it is possible to establish Nereocystis luetkeana at sites lacking kelp beds, restoration may be most effective when combined with conservation efforts, especially when the goal is to enhance an existing system. We caution, though, that one must consider population genetic effects when using transplants to enhance and conserve natural populations, in order to maintain adequate levels of population-genetic diversity. Once restoration methods are chosen, plantings should be dense and may have to be repeated each spring for several years in order to offset a high failure rate from any of the above-mentioned factors. We anticipate that the restoration of kelp and other macroalgal communities will become increasingly necessary as coastal development expands and as global change alters the nearshore environment. New restoration methodologies must be developed in response to these needs, and the transplant methodologies tested here provide an important first step.

Acknowledgements. We thank E. C. S. Duffield, D. O. Duggins, D. Bulthuis, D. Gillingham, K. Britton-Simmons, E. W. Duffield, R. Thom and J. Merrill for laboratory and subtidal field advice; J. E. Byrnes and C. J. Harley for their valuable edits; our field assistants and colleagues, C. Crandell, A. C. Manriquez, J. Gregg, K. Arnold, P. Margerum, M. Olson, J. Sausman, M. Jacobs, R. Wyeth, H. D'Agnes, B. Pister, R. Foley and K. Swenerton. Funding was provided by a Research Assistantship to L.T.C. in Estuarine Science and Coastal Zone Management at the Padilla Bay National Estuarine Research Reserve through the Padilla Bay Foundation with a gift from the Fayetta L. Erb Memorial Fund.

\section{LITERATURE CITED}

Ahn O, Petrell RJ, Harrison PJ (1998) Ammonium and nitrate uptake by Laminaria saccharina and Nereocystis luetkeana originating from a salmon sea cage farm. J Appl Phycol 10:333-340

Ambrose RF (1994) Mitigating the effects of a coastal powerplant on a kelp forest community - Rationale and requirements for an artificial reef. Bull Mar Sci 55:694-708

Antrim LD, Thom RM, Gardiner WW, Cullinan VI, Shreffler DK, Bienert RW (1995) Effects of petroleum products on bull kelp (Nereocystis luetkeana). Mar Biol 122:23-31

Bolton JJ, Lüning K (1982) Optimal-growth and maximal survival temperatures of Atlantic Laminaria species (Phaeophyta) in culture. Mar Biol 66:89-94

Britton-Simmons KH (2004) Direct and indirect effects of the introduced alga Sargassum muticum on benthic, subtidal communities of Washington State, USA. Mar Ecol Prog Ser $277: 61-78$

Carney LT (2003) Factors limiting the restoration of Nereocystis luetkeana (Mertens) Postels et Ruprecht (bull kelp). MS Thesis, University of Washington, Seattle

Cheney D, Oestman R, Volkhardt G, Getz J (1994) Creation of rocky intertidal and shallow subtidal habitats to mitigate for the construction of a large marina in Puget Sound, 
Washington. Bull Mar Sci 55:772-782

Chung IK, Brinkhuis BH (1986) Copper effects in early stages of the kelp, Laminaria saccharina. Mar Pollut Bull 17: 213-218

Delille B, Delille D, Fiala M, Prevost C, Frankignoulle M (2000) Seasonal changes of $\mathrm{pCO}_{2}$ over a subantarctic Macrocystis kelp bed. Polar Biol 23:706-716

Denny M, Gaylord B (2002) The mechanics of wave-swept algae. J Exp Biol 205:1355-1362

Devinny JS, Leventhal J (1979) New methods for massculture of Macrocystis pyrifera sporophytes. Aquaculture 17:241-250

Devinny JS, Volse LA (1978) Effects of sediments on development of Macrocystis pyrifera gametophytes. Mar Biol 48: 343-348

Deysher LE, Dean TA (1986) Interactive effects of light and temperature on sporophyte production in the giant-kelp Macrocystis pyrifera. Mar Biol 93:17-20

Druehl LD (1978) Distribution of Macrocystis integrifolia in British-Columbia as related to environmental parameters. Can J Bot 56:69-79

Duggins DO (1988) The effects of kelp forests on nearshore environments: biomass, detritus and altered flow. In: VanBlaricom GR, Estes JA (eds) The community ecology of sea otters, Vol 65. Springer-Verlag, New York, p 192-201

Duggins DO, Eckman JE (1994) The role of kelp detritus in the growth of benthic suspension feeders in an understory kelp forest. J Exp Mar Biol Ecol 176:53-68

Duggins DO, Eckman JE (1997) Is kelp detritus a good food for suspension feeders? Effects of kelp species, age and secondary metabolites. Mar Biol 128:489-495

Duggins DO, Eckman JE, Siddon CE, Klinger T (2001) Interactive roles of mesograzers and current flow in survival of kelps. Mar Ecol Prog Ser 223:143-155

Eckman JE, Duggins DO (1991) Life and death beneath macrophyte canopies - effects of understory kelps on growth-rates and survival of marine, benthic suspension feeders. Oecologia 87:473-487

Foster MS, Sousa WP (1985) Succession. In: Littler MM, Littler DS (eds) The handbook of phycological methods, Vol 5. Ecological field methods: macroalgae. Cambridge University Press, Cambridge, p 269-290

Garbary DJ, Kim KY, Klinger T, Duggins D (1999) Red algae as hosts for endophytic kelp gametophytes. Mar Biol 135: 35-40

Gardner WD (1980) Field assessment of sediment traps. J Mar Res 38:41-52

Hernandez-Carmona G, Garcia O, Robledo D, Foster M (2000) Restoration techniques for Macrocystis pyrifera (Phaeophyceae) populations at the southern limit of their distribution in Mexico. Bot Mar 43:273-284

Hoffman JR, Hansen LJ, Klinger T (2003) Interactions between UV radiation and temperature limit inferences from single-factor experiments. J Phycol 39:268-272

Hopkins R, Kain JM (1978) Effects of some pollutants on the survival, growth and respiration of Laminaria hyperborea. Estuar Coast Mar Sci 7:531-553

Hsiao S, Druehl LD (1973) Environmental control of gametogenesis in Laminaria saccharina. IV. In situ development of gametophytes and young sporophytes. J Phycol 9:160-164

Jara F, Cespedes R (1994) An experimental evaluation of habitat enhancement on homogeneous marine bottoms in Southern Chile. Bull Mar Sci 55:295-307

Kawamata S (2001) Adaptive mechanical tolerance and dislodgement velocity of the kelp Laminaria japonica in wave-induced water motion. Mar Ecol Prog Ser 211: 89-104
Koehl MAR, Alberte RS (1988) Flow, flapping, and photosynthesis of Nereocystis luetkeana - a functional comparison of undulate and flat blade morphologies. Mar Biol 99: 435-444

Kozloff E (1993) Seashore life of the northern Pacific coast: an illustrated guide to northern California, Oregon, Washington, and British Columbia, 2nd edn. University of Washington Press, Seattle

Kruckeberg A (1991) The natural history of Puget Sound country. University of Washington Press, Seattle

Lee JA, Brinkhuis BH (1988) Seasonal light and temperature interaction effects on development of Laminaria saccharina (Phaeophyta) gametophytes and juvenile sporophytes. J Phycol 24:181-191

Lee KN (1993) Compass and gyroscope: Integrating science and politics for the environment. Island Press, Washington, DC

Lobban CS, Harrison PJ (1994) Seaweed ecology and physiology. Cambridge University Press, New York

Lüning K (1980) Critical levels of light and temperature regulating the gametogenesis of three Laminaria species (Phaeophyceae). J Phycol 16:1-15

Lüning K, Pang SJ (2003) Mass cultivation of seaweeds: current aspects and approaches. J Appl Phycol 15:115-119

Marmorek D (2003) What is adaptive management? Presented in: Making it work: strategies for effective adaptive management workshop, City of Seattle and Washington Trout, February 13-14, 2003, Seattle

Martel A, Chia FS (1991) Oviposition, larval abundance; in situ larval growth and recruitment of the herbivorous gastropod Lacuna vincta in kelp canopies in Barkley Sound, Vancouver Island (British Columbia). Mar Biol 110: 237-247

Maxell BA, Miller KA (1996) Demographic studies of the annual kelps Nereocystis luetkeana and Costaria costata (Laminariales, Phaeophyta) in Puget Sound, Washington. Bot Mar 39:479-489

McLachlan J (1973) Growth media - marine. In: Stein JR (ed) The handbook of phycological methods, Vol 1. Culture methods and growth measurements. Cambridge University Press, Cambridge, p 25-51

Merrill JE (1991) Environmental mitigation with Nereocystis using long-line cultivation methods. Appl Phycol Forum: a newsletter for algal biotechnologies 8:1-2

Merrill JE, Gillingham DM (1991a) Seaweed management systems for use in habitat restoration, environmental management and mitigation. In: Puget Sound Research '91 proceedings. Puget Sound Water Quality Authority, Olympia, WA, p 354-363

Merrill JE, Gillingham DM (1991b) Bull kelp cultivation handbook. Publication No. NCRI-T-91-011. National Coastal Research and Development Institute, Portland, OR

Murray CL, Marmorek DR, Kurz WA (2000) De-mystifying adaptive management-instructor's manual, rev edn Prepared by ESSA Technologies, Vancouver, BC for BC Forest Service, Victoria

Neushul M (1967) Studies of subtidal, marine vegetation in Western Washington. Ecology 48:83-94

North WJ (1971) Mass cultured Macrocystis as a means of increasing kelp stands in nature. In: Proc Intl Seaweed Symp 7. Science Press, Sapporo, p 349-399

North WJ (1976) Aquacultural techniques for creating and restoring beds of giant kelp, Macrocystis spp. J Fish Res Board Can 33:1015-1023

Reed DC (1990) The effects of variable settlement and early competition on patterns of kelp recruitment. Ecology 71: 776-787 
Reimers H, Branden K (1994) Algal colonization of a tire reef influence of placement date. Bull Mar Sci 55:460-469

Robles CD (1982) Disturbance and predation in an assemblage of herbivorous diptera and algae on rocky shores. Oceologia 54:23-31

Robles CD, Cubit J (1981) Influence of biotic factors in an upper intertidal community: dipteran larvae grazing on algae. Ecology 62:1536-1547

Shaffer JA (1998) Kelp bed habitats of the inland waters of Western Washington. In: Droscher TW, Fraser DA (eds) Proceedings Puget Sound Research 1998. Puget Sound Water Quality Authority, Olympia, WA, p 1-10

Shaffer JA (2004) Preferential use of nearshore kelp habitats by juvenile salmon and forage fish. In: Droscher TW, Fraser DA (eds) Proceedings of the 2003 Georgia Basin/ Puget Sound Research Conference. Puget Sound Water Quality Authority, Olympia, WA, p 1-11

Shaffer JA, Parks DS (1994) Seasonal-variations in and observations of landslide impacts on the algal composition of a Puget Sound nearshore kelp forest. Bot Mar 37: 315-323

Shaffer JA, Doty DC, Buckley RM, West JE (1995) Crustacean

Editorial responsibility: Otto Kinne (Editor-in-Chief), Oldendorf/Luhe, Germany community composition and trophic use of the drift vegetation habitat by juvenile splitnose rockfish Sebastes diploproa. Mar Ecol Prog Ser 123:13-21

Swanson AK, Druehl LD (2000) Differential meiospore size and tolerance of ultraviolet light stress within and among kelp species along a depth gradient. Mar Biol 136:657-664

Terawaki T, Hasegawa H, Arai S, Ohno M (2001) Management-free techniques for restoration of Eisenia and Ecklonia beds along the central Pacific coast of Japan. J Appl Phycol 13:13-17

Thom RM, Hallum L (1990) Long-term changes in the areal extent of tidal marshes, eelgrass meadows and kelp forests of Puget Sound. In: Wetland Ecosystem Team (eds) Final report to Office of Puget Sound, Region 10, US Environmental Protection Agency, EPA 910/9-91-005 (FRI-UW9008). Fisheries Research Institute, School of Fisheries, University of Washington, Seattle

Tom Dieck I (1992) North Pacific and North Atlantic digitate Laminaria species (Phaeophyta) - hybridization experiments and temperature responses. Phycologia 31:147-163 Vadas R (1972) Ecological implications of culture studies on Nereocystis luetkeana. J Phycol 8:196-203

Submitted: December 9, 2004; Accepted: May 10, 2005 Proofs received from author(s): August 31, 2005 